\title{
STUDENTS CRITICAL THINKING SKILL IN SOLVING SCIENTIFIC LITERACY USING A METACOGNITIVE TEST BASED ON SCIENTIFIC LITERACY
}

\author{
Zakaria Sandy Pamungkas*1, Nonoh Siti Aminah ${ }^{2}$, Fahru Nurosyid ${ }^{3}$ \\ 1,2 Physics Education of Post Graduate Program, Sebelas Maret University, Surakarta, Indonesia \\ ${ }^{3}$ Physics Department of Post Graduate Program, Sebelas Maret University, Surakarta, Indonesia \\ *corresponding address: pamungkaszakaria@student.uns.ac.id
}

Received: August $7^{\text {th }}, 2018$. Accepted: October $24^{\text {th }}, 2018$. Published: October $28^{\text {th }}, 2018$

\begin{abstract}
The purpose of this research is to measure students critical thinking skill in solving scientific literacy using a metacognitive test based on scientific literacy. This research is descriptive research. The subject of this research is 99 students of grade XI in SMA Batik 2 Surakarta. Data collection methods used are test methods which using a metacognitive test based on scientific literacy. Data analysis techniques use quantitative descriptive analysis. The results showed that the achievement of scientific literacy is still low at below 50\% for all category. This is due to students critical thinking skill in solving all category of scientific literacy problem is still low. Low student critical thinking skill in solving science as a body of knowledge in the assessment stage with the percentage achievement is $21 \%$. Low percentage achievement of critical thinking skill in solving science as a way of thinking is a clarification (34\%), assessment (46\%), inference (26\%), and strategy (12\%). Low percentage achievement of critical thinking skill in solving science as a way of investigating is assessment (39\%), inference (5\%), and strategy (6\%). Low student critical thinking skill in solving science as an interaction between technology and society in the assessment stage with the percentage achievement is $31 \%$.
\end{abstract}

(C) 2018 Physics Education, UIN Raden Intan, Lampung, Indonesia.

Keyword: critical thinking skill, metacognitive test, scientific literacy.

\section{INTRODUCTION}

The rapid advance of science and technology is one of the impacts of globalization which causing the mindset of a society increasingly critical to the need of their life (Rachmatullah, Diana, \& Rustaman, 2016). This causes students not only required to have cognitive competence but also soft skills that can help students in overcoming the rapid advance of science and technology. One of the soft skill that related to science and technology development is scientific literacy (Adawiyah \& Wisudawati, 2017). This is due to soft skill in the form of science literacy is able to make students to relate natural phenomenon to concepts that have been learned in school. The scientific literacy of students is expected to making progress in understanding the natural world (Good, Hafner, \& Peebles, 2000).
Science Literacy is the ability to engage with science on related problems and with scientific ideas as a reflection of citizens (Asyhari, 2017). Scientific literacy is the goal of physics education as a basis for science education (Holbrook \& Rannikmae, 2009). This is due to the main goals of science education are to provide an opportunity for students to make decisions about socio-scientific issues that affect their lives (OECD, 2004). This showed that scientific literacy is a necessary element of education in our modern science and technology. This cause teachers of science to engage a student in studied history, philosophy, and practice of science (Udeani, 2013).

Building students scientific literacy can be done through training student critical thinking skill. This is due to students' critical thinking skills can help students to solve problems related to 
scientific literacy. Critical thinking is a self-regulatory judgment that results in interpretation, analysis, evaluation, and inference as well as an explanation of the evidential, conceptual, methodological, or contextual (White, Stains, Escriu-sune, Medaglia, \& Rostamnjad, 2011). Critical thinking also can raise vital questions and problems to formulate them clearly, gather and asses relevant information to think open-mindedly (Duron, Limbach, \& Waugh, 2006). So, it can be concluded that critical thinking skill will encourage students to understand the problem and make an alternative problem solving with the problem-solving stage is clarification, assessment, inference, and strategy (Jacob \& Sam, 2008).

Student critical thinking skill in solving scientific literacy can be measure using metacognitive assessment instruments based on science literacy. This is due to critical thinking as the set of skill which enables to solve a problem logically and reflect autonomously by means metacognitive regulation (Gotoh, 2016). Metacognitive refers to ways of raising awareness of thinking and learning process (Yanti, Distrik, Khasyyatillah, \& Khasyyatillah, 2017). It is shown that metacognitive knowledge plays an important role in the learning process because metacognitive is crucial in regulating and controlling the cognitive process of a person in learning and thinking (Warni, Sunyono, \& Rosidin, 2018). The instrument of metacognitive assessment based on scientific literacy is an instrument of scientific literacy assessment which consisting of metacognitive knowledge question that is declarative knowledge, procedural knowledge, and conditional knowledge. Declarative knowledge is knowledge about oneself as a learner and about what factors influence one's performance, procedural knowledge is knowledge about doing things which are represented as heuristics and strategies, conditional knowledge is knowledge about knowing when and why to use declarative and procedural knowledge (Schraw, 1998).

Based on the description, it can be concluded that the metacognitive test based on scientific literacy can measure student critical thinking skill in solving scientific literacy. Student critical thinking skill as an ability to solve problems is one of the goals of learning physics (Supeno, Subiki, \& Rohma, 2018). Therefore it's important to analyze students' critical thinking skill in solving scientific literacy.

\section{METHOD}

This research is quantitative descriptive research. This research was conducted in the semester II of academic year 2017/2018 in SMA Batik 2 Surakarta. A sample in this research is 99 students of grade XI in SMA Batik 2 Surakarta. The method used in this research is survey method which surveys research procedure: 1) Research objective, 2) Concepts, 3) Questioner, 4) Population, 5) Sampling, 6) Data collection, 7) Data processing, 8) Interpretation (Biemer \& Lyberg, 2003).

Data collection method used is a metacognitive test based on scientific literacy. The test is used to find out the profile of students critical thinking skill in solving scientific literacy. The questions on the test sheet consisted of 4 problems about a category of scientific literacy that is science as a way of thinking, science as a way of investigating, science as a body of knowledge, science and its interaction with technology and society (Chiappetta, Sethna, \& Fillman, 1991; Udeani, 2013). Each of the scientific literacy problems contained three question about metacognitive knowledge that is declarative, procedural, and conditional knowledge (Rompayom, Tambunchong, Wongyounoi, \& Dechsri, 2010). It can analyze student critical thinking skills in solving scientific literacy. The indicator 
of critical thinking skill in solving scientific literacy is adopted from Jacob and Sam that is clarification, assessment, inference and strategy (Jacob \& Sam, 2008). Data analysis technique used in this research is quantitative descriptive analysis. Quantitative descriptive analysis technique is used to process the data obtained from the test in the form of a descriptive percentage of critical thinking skill in solving scientific literacy.

\section{RESULTS AND DISCUSSION}

Student answer in a metacognitive test based on scientific literacy is analyzed to describe student critical thinking skill in solving scientific literacy. Critical thinking skill in solving scientific literacy is thinking skill to know the concept underlying a problem (clarification), visualize the problem schematically to see a relation of the variables or basic concept (assessment), giving strategy to solve a problem (inference) and evaluate strategy (Laurens, 2010). Percentage achievement of student scientific literacy for each category can be seen in Figure 1.

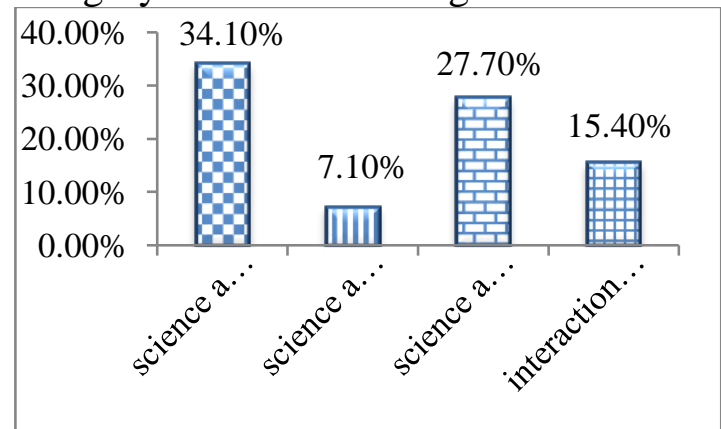

Figure 1. Percentage achievement of student science literacy in each category

In figure 1 it can be seen that the achievement of science literacy of students in each category is still low. Percentage achievement for a category of science a body of knowledge is $34,1 \%$. This shows that students still have difficulty in explaining situations /questions that require students to remember knowledge of information. Percentage achievement for a category of science as a way of thinking is $7,1 \%$. This suggests that students still have difficulty making about experiments or thinking activities. Percentage achievement for a category of science a way of investigating is $27,7 \%$. This shows that students are still having difficulty in presents a scientific method and problem solving based on fact and evidence. Percentage achievement for a category of an interaction of science, technology, and society is still low with the percentage of achievement is $15.4 \%$. This shows that students still do not understand the application of science and technology for society. Low percentage achievement of scientific literacy due to student still don't have more resources for continuing education. Some resources such as books and the internet can explore the latest advances in scientific research (Ogunkola, 2013). It can make student to increase critical thinking skill. Critical thinking enables the student to improve themselves ability to criticize, questioning, evaluating, and reflecting (Zhang \& Kim, 2018). Furthermore, it's important to analyze student critical thinking skill in solving each category of scientific literacy: science as a body of knowledge, science as a way of thinking, science as a way of investigating, and interaction between science, technology, and society.

Percentage achievement of student critical thinking skill in solving a category of science as a body of knowledge can be seen in Figure 2.

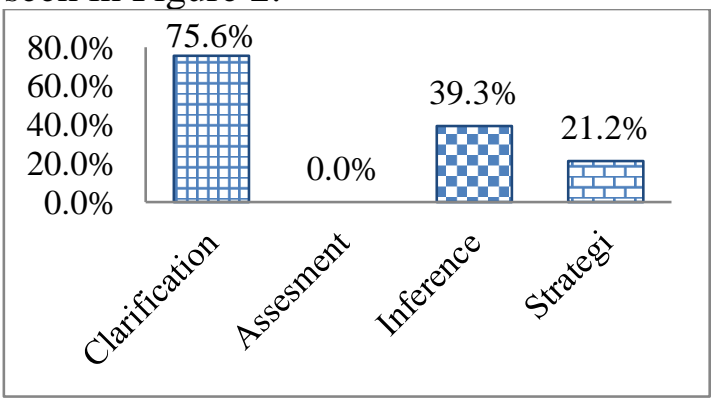

Figure 2. Percentage achievement of student critical thinking skill in solving a category of science as a body of knowledge 
In figure 2 it can be seen that in the category of scientific literacy as a science of body of knowledge, it is found that the achievement of critical thinking skill is $75.6 \%$ for clarification stage, $0 \%$ for assessment, $39.3 \%$ for inference, and $21.2 \%$ for strategy. This shows that the low critical thinking skill of students in solving the scientific literacy for category science as a body of knowledge is in the assessment stage. This is due to students only understand the concepts and laws of physics without being able to understand the physical representation of the concepts and laws of physics. This is due to teaching materials used only to explain the concept of laws of physics without explaining further related to the meaning of the concept of laws of physics. Student answer in solving a category of science as a body of knowledge can be seen in figure 3.

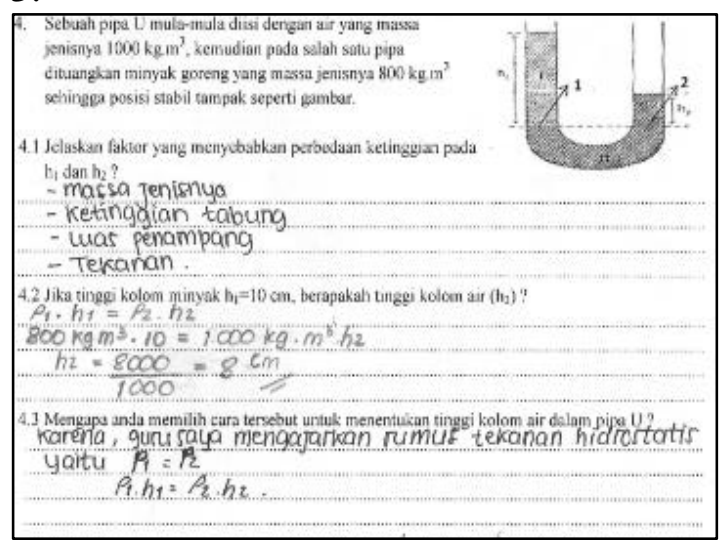

Figure 3. Student answer in solving a category of science as a body of knowledge

In figure 3 it can be seen that scientific literacy problem in a category of science as a body of knowledge about $U$ tube concept. Based on figure 3 , it can be seen that students have been able to explain the concept of physics on the U tube problem. This is shown by the students' answers that the factors that cause differences in tube height are density, altitude, crosssectional area and pressure. The answer shows that students are able to contact a problem with relevant concepts and theories. In this category of science as a body of knowledge, students are also able to determine steps or strategies for solving a problem. This is shown by the students' answers that the pressure on a straight line is the same value so $\rho_{1} \cdot h_{1}=\rho_{2} \cdot h_{2}$.

Percentage achievement of student critical thinking skill in solving a category of science as a way of thinking can be seen in Figure 4.

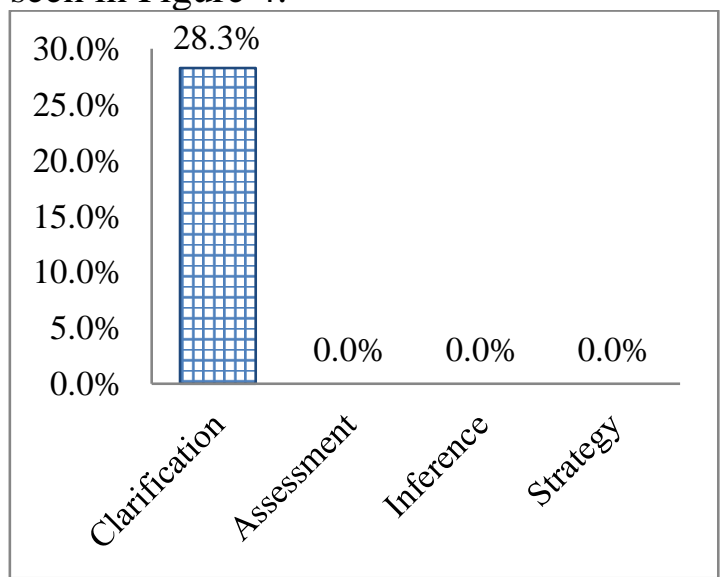

Figure 4. Percentage achievement of student critical thinking skill in solving a category of science as a way of thinking.

Figure 4 shows about percentage achievement for a category of scientific literacy as a science a way of thinking. It is found that the achievement of critical thinking skill in the clarification stage is $28.3 \%, 0 \%$ for assessment, $0 \%$ for inference, and $0 \%$ for strategy. Results obtained in line with research (Rusilowati, Kurniawati, Nugroho, \& Widiyatmoko, 2016) that students skills in critical thinking are lacking for a category of scientific literacy as a science a way of thinking. The data shows that students' critical thinking skills used in solving science literacy in the science a way of thinking category are only in the clarification stage. This indicates that the student is still having difficulty in explaining, conceptualizing, and determining the settlement step and evaluating the settlement step. The low ability of students in explaining and determining and evaluating the settlement step because students are less able to 
calculate the comparison formula. This is because the training questions given by the teacher during the learning process only at the level of C3 (application) has not reached the level of C4 (analyze). So that student is poorly trained in solving problems that require the ability to think a level of analysis is a matter of comparison. Student answer in solving a category of science as a way of thinking can be seen in figure 5 .

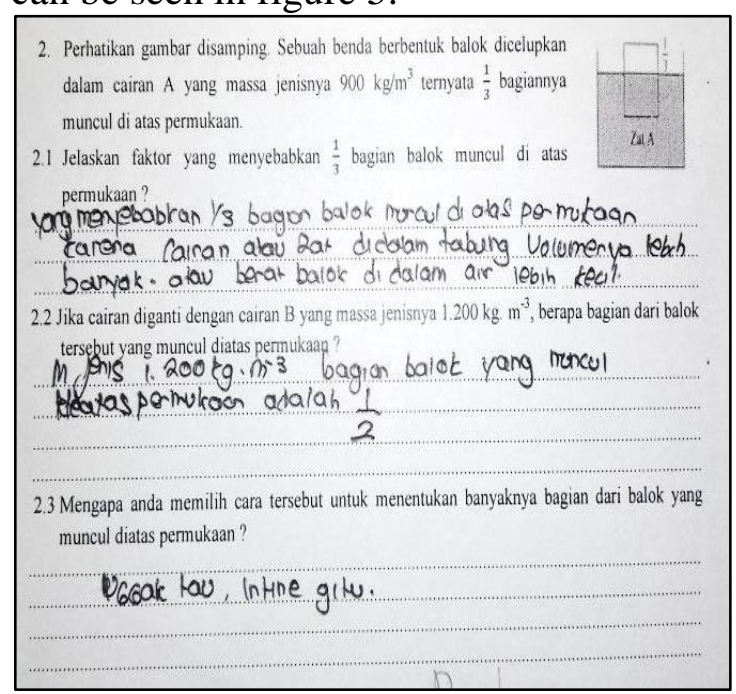

Figure 5. Student answer in solving a category of science as a way of thinking.

In figure 5 it can be seen that scientific literacy problem in a category of science as a way of thinking about Archimedes Law. Figure 5 show that students in solving a category of science as a way of thinking with try and error. This is shown from the students' answers that the factors that cause the condition of floating objects are due to differences in the volume ratio between objects and fluids whereas what causes floating objects is the density of objects smaller than the density of fluid so that buoyancy is greater than gravity. It proves that a student can not think imaginatively and logically. Imaginatively and logically can be train based on reality through sketch strategy of knowledge (Amin, Abdullah, \& Malago, 2018).

Percentage achievement of student critical thinking skill in solving a category of science as a way of thinking can be seen in Figure 6.

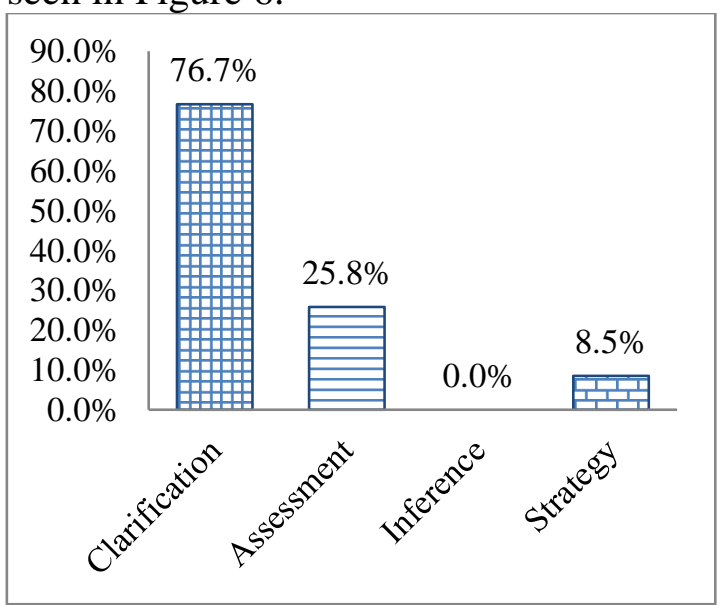

Figure 6. Percentage achievement of student critical thinking skill in solving a category of science as a way of investigating.

Figure 6 show about percentage achievement for a category scientific literacy as a science a way of investigating, it is found that the achievement of critical thinking ability at $76.7 \%$ clarification stage, $25,8 \%$ for assessment, $0 \%$ for inference, and strategy equal to $8,5 \%$. The data shows that the students' least critical thinking skill in solving scientific literacy in the category of science as a way of thinking is in the stage of inference and strategy. This is because students are poorly trained in analyzing the tables of observations. One of the factors that cause it is the absence of practicum or experimental activities during the learning process so that students are poorly trained in making observation tables that cause students difficulties in analyzing information based on the observation table. This is supported by Rasmawan that the common mistake is that students judge a statement to be subjective and do not see and use the information provided in the table (Rahmat Rasmawan, 2017). Student answer in solving a category of science as a way of investigating can be seen in figure 7 . 


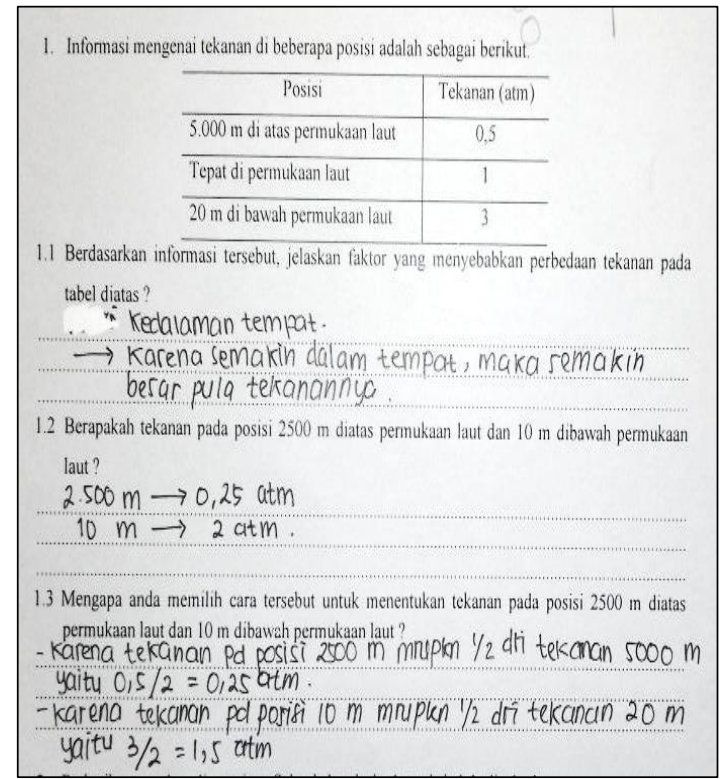

Figure 7. Student answer in solving a category of science as a way of investigating.

In Figure 7 it can be seen that students answer in a category of science as a way of investigating have been able to solve problems related to factors that cause pressure differences. Students argue that the factor that causes a pressure difference is the depth of the object. This shows that students are able to explain the concepts and theories of a problem. However, in this category, students still experience difficulties in solving mathematical problems about hydrostatic pressure which causes students to draw conclusions through reasoning by comparing the height and depth of an object. In fact, hydrostatic pressure is not only influenced by the position through external pressure with the mathematical equations used is $\mathrm{P}=\mathrm{P}_{0} \pm \rho \mathrm{gh}$. One of the efforts to improve students' critical thinking is through improvement metacognitive regulation. This agrees with (Gurcay \& Ferah, 2018) that metacognitive self-regulation can increase student critical thinking skill.

Percentage of achievement of student critical thinking skill in solving a category of science as an interaction between technology and society can be seen in Figure 8.

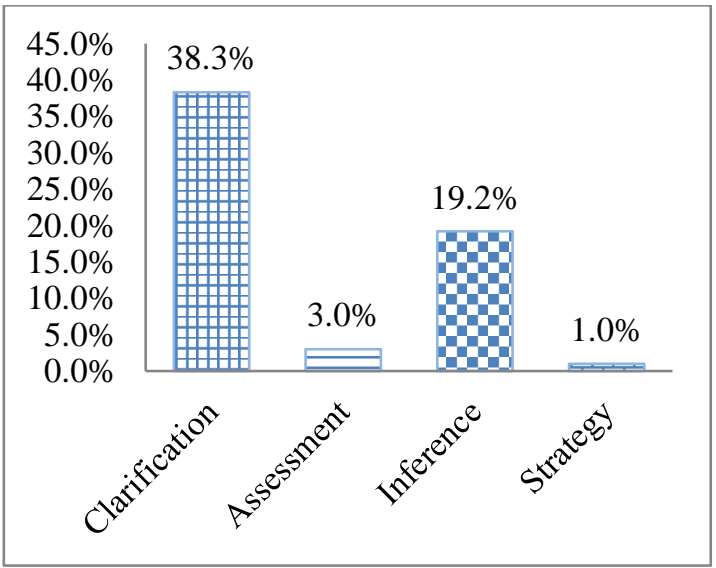

Figure 8. Percentage of achievement of student critical thinking skill in solving a category of science as an interaction between technology and society.

Figure 8 shows about percentage achievement for a category of scientific literacy as the interaction of science, technology, and society. It is found that the achievement of critical thinking skill at the clarification stage is $38.3 \%, 3 \%$ for assessment, $19.2 \%$ for inference, and $1 \%$ for strategy. The data shows that students' critical thinking skills are in very low in solving science literacy category as an interaction of science, technology, and society is in the stage of assessment and strategy. The lack of students' critical thinking skills at the assessment stage indicates that students are still having difficulty explaining the concept of laws of physics applications that are in daily life. This is due to lack of explanation of the concept of physics in applications in daily life. The lack of students' critical thinking skills at the strategic stage shows that students are still having difficulties in evaluating the proposed settlement measures. This is because the teacher does not pay attention to the process so that physics will be a science that just memorizes the formula alone will foster students' negative stigma toward physics (Lisdianto, Masykuri, \& Aminah, 2015). Student answer in solving a category of science as an interaction between technology and society can be seen in figure 9 . 


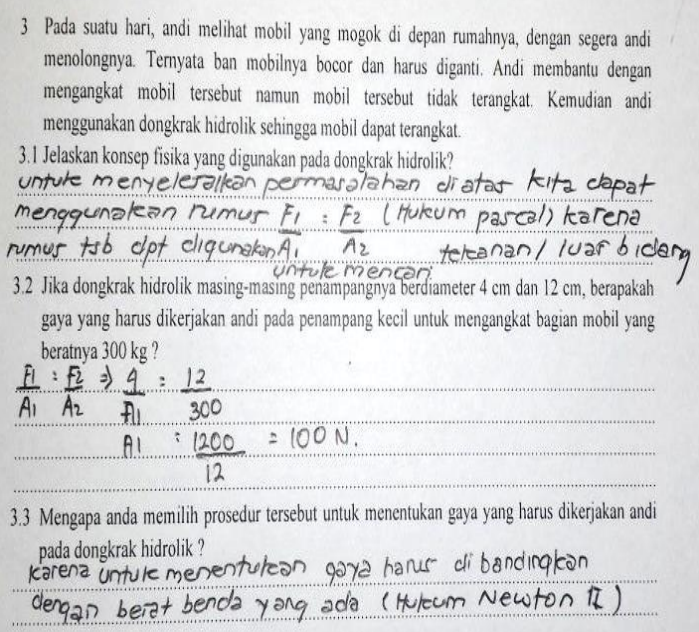

Figure 9. Student answer in solving a category of science as an interaction between technology and society.

Figure 9 shows that students can solve a problem of science as an interaction between technology and society that is hydraulic jack application. This is shown from students' answers that the physics concept used in hydraulic jack is pascal law because of the difference in a crosssectional area used. The answer shows that students already have declarative knowledge that aims to understand the meaning of test and solving a problem with relevant concepts and theories. It's similar to the Wulandari and Nurhayati research that critical thinking can make students to understand the meaning of test question (Yuniasti \& Wulandari, 2018). Students also have the procedural knowledge to determine steps or strategies for solving a problem. This is shown by the students' answers to procedural related problems that the pressure at each point is the same so that the pressure is directly proportional to the cross-sectional area. However, students do not have conditional knowledge that causes students to experience errors in evaluating the completion steps. This is shown based on errors in students' answers in entering data into the magnitude of the predetermined equation. The thing that causes this error is because students memorize more formulas without understanding further about the quantities contained in the formula or equation.

\section{CONCLUSION}

In this research, the investigation had been conducted to determine student critical thinking skill in solving scientific literacy. The results of student scientific literacy are still low that is below 35\%. This is due to students critical thinking skill in solving scientific literacy problem is still low. Low student critical thinking skill in solving science as a body of knowledge in the assessment stage (21\%). Low percentage achievement of critical thinking skill in solving science as a way of thinking is a clarification (34\%), assessment (46\%), inference $(26 \%)$, and strategy (12\%). Low percentage achievement of critical thinking skill in solving science as a way of investigating is an assessment (39\%), inference (5\%), and strategy $(6 \%)$. Low student critical thinking skill in solving science as an interaction between technology and society in the assessment stage with the percentage achievement is $31 \%$. These results indicate that the teacher has not built students' critical thinking skills: clarification, assessment, inference, and strategy. This is due to the teacher has not conducted an assessment of students' critical thinking skills. Therefore, the teacher needs to do an assessment of students' critical thinking skill that is used as evaluation material to determine the learning model based on students' critical thinking skills weaknesses

\section{REFERENCES}

Adawiyah, R., \& Wisudawati, A. W. (2017). Pengembangan Instrumen Tes Berbasis Literasi Sains : Menilai Pemahaman Fenomena Ilmiah Mengenai Energi. Indonesian Journal of Curriculum and Educational Technology Studies, 5(2), 112-121. 
https://doi.org/http://dx.doi.org/10.15 294/ijcets.v3i1.8675

Amin, B. D., Abdullah, H., \& Malago, J. D. (2018). Sketch strategy of knowledge in physics learning and its influence on metacognitive. Educational Research and Reviews, 13(7), 230-235. https://doi.org/10.5897/ERR2017.32 93

Asyhari, A. (2017). Literasi Sains Berbasis Nilai-Nilai Islam dan Budaya Indonesia. Jurnal Ilmiah Pendidikan Fisika Al-Biruni, 6(1), 137.

https://doi.org/10.24042/jpifalbiruni. v6i1.1584

Biemer, P. P., \& Lyberg, L. E. (2003). Introduction to Survey Quality. https://doi.org/10.1002/0471458740

Chiappetta, E. L., Sethna, G. H., \& Fillman, D. A. (1991). A quantitative analysis of high school chemistry textbooks for science literacy: Themes and expository learning aids. Journal of Research in Science Teaching, 28(10), 939-951. https://doi.org/https://doi.org/10.100 2/tea.3660281005

Duron, R., Limbach, B., \& Waugh, W. (2006). Critical Thinking Framework For Any Discipline. International Journal of Teaching and Learning in Higher Education, 17(2), 160-166. https://doi.org/10.1016/j.nepr.2006.0 9.004

Good, R., Hafner, M., \& Peebles, P. (2000). Scientific understanding of sexual orientation: implications for science education. The American Biology Teacher, 62(5), 326-330. https://doi.org/10.1662/00027685(2000)062[0326:SUOSOI]2.0.C $\mathrm{O} ; 2$

Gotoh, Y. (2016). Development of critical thinking with metacognitive regulation. 13th International Conference on Cognition and Exploratory Learning Digital Age,
(Celda), 353-356. Retrieved from https://files.eric.ed.gov/fulltext/ED57 1408.pdf

Gurcay, D., \& Ferah, H. O. (2018). High School Students' Critical Thinking Related to Their Metacognitive SelfRegulation and Physics Self-Efficacy Beliefs. Journal of Education and Training Studies, 6(4), 125-130. https://doi.org/10.11114/jets.v6i4.29 80

Holbrook, J., \& Rannikmae, M. (2009). The meaning of scientific literacy. International Journal of Environmental and Science Education, 4(3), 275-288. https://doi.org/10.1080/09500690601 007549

Jacob, S. M., \& Sam, H. K. (2008). Measuring critical thinking in problem solving through online discussion forums in first-year university mathematics. Imecs 2008: International Multiconference of Engineers and Computer Scientists, Vols I and Ii, I, 816-821.

Laurens, T. (2010). Penjenjangan Metakognisi Siswa yang Valid dan Reliabilitas. Jurnal Pendidikan Dan Pembelajaran, 17(2), 201-213.

Lisdianto, D., Masykuri, M., \& Aminah, N. S. (2015). Pengembangan Integrated Contextual Module (ICM) Untuk Meningkatkan Kreativitas Dan Kemampuan Berpikir Kritis Siswa Smk Pada Pokok Bahasan Sifat Mekanik Bahan (Pembelajaran Fisika Di SMK Veteran 1 Sukoharjo Tahun Ajaran 2014/2015). Jurnal Inkuiri, 4(4), 2252-7893. Retrieved from

http://jurnal.fkip.uns.ac.id/index.php/ sains

OECD. (2004). The PISA 2003 Assessment Framework. Oecd, 194. https://doi.org/10.1787/97892641017 39-en

Ogunkola, B. J. (2013). Scientific Literacy: Conceptual Overview, 
Importance, and Strategies for Improvement. Journal of Educational and Social Research, 3(1), 265-274. https://doi.org/10.5901/jesr.2013.v3n $1 \mathrm{p} 265$

Rachmatullah, A., Diana, S., \& Rustaman, N. Y. (2016). Profile of middle school students on scientific literacy achievements by using scientific literacy assessments (SLA). AIP Conference 1708(2016). https://doi.org/10.1063/1.4941194

Rahmat Rasmawan. (2017). Profil Keterampilan Kerja Ilmiah dan Berpikir Kritis Siswa SMA di Kalimantan Barat. Edusains, 9(1), 60-70.

https://doi.org/http://dx.doi.org/10.15 408/es.v9i1.4417

Rompayom, P., Tambunchong, C., Wongyounoi, S., \& Dechsri, P. (2010). The Development of Metacognitive Inventory to Measure Students' Metacognitive Knowledge Related to Chemical Bonding Conceptions. International Association for Educational Assessment (IAEA 2010), (Iaea), 1$7 . \quad$ Retrieved from http://selectscore.com/fullpaper/221. pdf

Rusilowati, A., Kurniawati, L., Nugroho, S. E., \& Widiyatmoko, A. (2016). Developing an instrument of scientific literacy asessment on the cycle theme. International Journal of Environmental and Science Education, 11(12), 5718-5727.

Schraw, G. (1998). Promoting general metacognitive awareness. Instructional Science, 26(1), 113125.

https://doi.org/10.1023/A:100304423 1033

Supeno, S., Subiki, S., \& Rohma, L. W. (2018). Students' Ability In Solving Physics Problems on Newtons' Law of Motion. Jurnal Ilmiah Pendidikan Fisika Al-Biruni, 7(1), 59-70. https://doi.org/10.24042/jipfalbiruni. v7i1.2247

Udeani, U. (2013). Quantitative Analysis of Secondary School Biology Textbooks for Scientific Literacy Themes. Research Journal in Organizational Psychology \& Educational Studies, 2(1), 39-43.

Warni, Sunyono, \& Rosidin. (2018). Measuring metacognitive ability based on science literacy in dynamic electricity topic Measuring metacognitive ability based on science literacy in dynamic electricity topic. Journal of Physics: Conference Series, 948. https://doi.org/10.1088/17426596/948/1/012041

White, B. B., Stains, M., Escriu-sune, M., Medaglia, E., \& Rostamnjad, L. (2011). A Novel Instrument for Assessing. Journal of College Science Teaching, 40, 102-107.

Yanti, H., Distrik, I. W., Khasyyatillah, I., \& Khasyyatillah, I. (2017). Profile of Senior High School Metacognitive Ability in Solving Problems of Abstraction on Physics Material. Jurnal Ilmiah Pendidikan Fisika AlBiruni, 6(2), 241. https://doi.org/10.24042/jipfalbiruni. v6i2.2061

Yuniasti, A., \& Wulandari, R. (2018). The Relationship Between Verbal Ability and Critical Thinking Skill: The Implementation of Susan Loucks Horsley Model. Jurnal Ilmiah Pendidikan Fisika Al-Biruni, 07(April), 89-97.

Zhang, L., \& Kim, S. (2018). Critical Thinking Cultivation in Chinese College English Classes. English Language Teaching, 11(8), 1. https://doi.org/10.5539/elt.v11n8p1 